\title{
Head and Neck Primary Mucosal Melanoma: Report of 17 Cases
}

\author{
Btissaam Belhoucha ${ }^{1}$, Zahra Essaadi², Youssef Rochdi' ${ }^{1}$, Hassan Nouri' ${ }^{1}$, Lahcen Aderdour ${ }^{1}$, \\ Mona Khouchani' ${ }^{2}$ Abdelaziz Raji ${ }^{1}$ \\ ${ }^{1}$ Department of ENT, CHU Med VI, Marrakech, Morocco \\ ${ }^{2}$ Department of Oncology and Radiotherapy, CHU Med VI, Marrakech, Morocco \\ Email: btissambelhoucha@gmail.com
}

Received 12 February 2015; accepted 28 February 2015; published 4 March 2015

Copyright (C 2015 by authors and Scientific Research Publishing Inc.

This work is licensed under the Creative Commons Attribution International License (CC BY). http://creativecommons.org/licenses/by/4.0/

\section{(c) (i) Open Access}

\begin{abstract}
Introduction: Mucosal melanoma (MM) is a rare disease, accounting for $1.7 \%$ - $3 \%$ of all melanomas and $8 \%$ of all head and neck melanomas. It's a rare cancer with a very poor prognosis. Materials and Methods: We retrospectively reviewed the records of 17 patients with primary mucosal melanomas of the head and neck who were diagnosed between January 2007 and December 2012. Results: Our patient population included 9 women and 8 men. The age ranged from 61 to 75 years. The primary site of disease was in the sinonasal cavity for 12 patients $(70 \%)$ and oral cavity for 5 patients. Treatment modalities for mucosal melanoma include surgical resection with or without neck dissection, immunochemotherapy, and radiation therapy (RT). 15 patients had attempted curative resections. Two patients received palliative radiation therapy as the primary treatment and chemotherapy as the adjuvant treatment. Discussion: Primary mucosal melanoma is a rare cancer and represents only $1.7 \%-3 \%$ of all primary melanomas [1]-[3]. Mucosal melanoma must always be considered for multimodality therapy: surgical excision, medical oncology, and radiation therapy. Despite its radioresistant nature of tumor, the role of radiation therapy following surgical intervention has typically been advocated.
\end{abstract}

\section{Keywords}

Malignant Melanoma, Oral Mucosa, Sinonasal Cavity, Radiation Therapy, Prognosis

\section{Introduction}

Mucosal melanoma is a rare disease, accounting for $1.7 \%$ - 3\% of all melanomas and $8 \%$ of all head and neck melanomas. It's a rare cancer with a very poor prognosis. Oral mucosal melanoma typically presents earlier than

How to cite this paper: Belhoucha, B., Essaadi, Z., Rochdi, Y., Nouri, H., Aderdour, L., Khouchani, M. and Raji, A. (2015) Head and Neck Primary Mucosal Melanoma: Report of 17 Cases. International Journal of Otolaryngology and Head \& Neck Surgery, 4, 86-93. http://dx.doi.org/10.4236/ijohns.2015.42016 
sinonasal mucosal melanoma. Head and neck melanoma also tends to affect a slightly older aged group than melanomas in other sites; it includes a mean age of 60 - 69 years and equal male/female preponderance. It involves in decreasing order of frequency, the sinonasal cavity (50\%), oral cavity (45\%), and other sites (5\%) such as pharynx, larynx, and upper esophagus [1] [4] [5].

There is typically decreased nodal metastasis in comparison to cutaneous melanoma. The prognosis for a patient with mucosal melanoma is dismal, with a 5-year survival rate of 5\% to $17 \%$ [1] [4] [5]. The purpose of this article is to discuss the optimal treatment and outcomes for head and neck mucosal melanoma.

\section{Materiels and Methods}

We retrospectively reviewed the records of 17 patients with primary mucosal melanomas of the head and neck who were diagnosed and prospectively followed up at the department of ENT surgery and the department of oncology between January 2007 and December 2012. We have exclude from the study Patients with cutaneous melanomas, including cutaneous melanomas encroaching on the sinonasal area, patients with associated pathology that may influence the overall survival of our patients (kidney, lung or heart disease) and lost sight patients. Limitations of our study include its retrospective nature and its limited patient numbers.

Patient and disease characteristics included age, gender, race, and primary site of disease, disease stage, and treatment received have been reviewed.

\section{Results}

Sinonasal mucosal melanoma was defined as a pathological diagnosis of malignant melanoma arising on the mucosa of the oral cavity, nasal cavity, nasopharynx, or sinuses, according to the final pathological report. In all cases the diagnosis of mucosal melanoma was established after standard microscopic and immunohistochemical examinations (positivity for HMB-45 and S-100 protein) of incisional biopsy specimens. Thorough history taking and physical examination ruled out the possibility of occult melanotic lesions elsewhere in the body, to finally declare the lesions "primary."

Disease was almost equally common in men and women; our patient population included 9 women and 8 men. The age ranged from 61 to 75 years, with median age of 67, 83 years for patient with sinonasal melanoma and 70, 40 years for patient with patient with oral cavity melanoma.

The primary site of disease was in the sinonasal cavity for 12 patients (70\%) and oral cavity for 5 patients (30\%). Patients' most common complaints included epistaxis (10 patients: 58\%), facial pressure (5 patients: $30 \%$ ) and nasal obstruction (6 patients: 35\%). Most frequently sino nasal tumors were in the maxillary sinus (6 patients), nasal cavity (3 patients) and nasal septum (2 patients) (Figure 1 and Figure 2).

Symptoms of oral melanomas vary and include a bleeding lump (3 patients) and pain (1 patient); 4 patients had a history of a continuously growing exophytic hyperplastic mass of a dark color (Figure 3).

Mucosal melanoma of oral cavity was most frequent on the hard palate (2 patients) and less frequently in the buccal mucosa (1 patient), mandibular gingiva (1 patient) and alveolar ridge (1 patient).

The median duration of symptoms before presenting to an otolaryngologist was 2 months (range 1 month to 04 months). All patients with oral mucosal melanoma (5 pattients) present with neck metastasis while only 2 patients of sinonasal melanoma present initially with neck involvement (Figure 4).

The tumors were stratified according to UICC (Union Internationale Contre le Cancer) staging [5] [6]: stage I, confined to the primary site (10 patients); stage II, positive cervical lymph nodes (05 patients); and stage III, distant metastases (02 patients). Of these patients, the liver and the lung were the most common locations.

According to TNM classification, The sinonasal tumors were stratified T3N0M0 in three cases, T4N2M0 in two cases, T1N0M0 in six cases and T4N3M+ in one case; The oral tumors were stratified T1N1M0 in two cases; T1N2M0 in one case, T4N2M0 in one case and T4N3M+ in one case.

Treatment modalities for mucosal melanoma include surgical resection with or without neck dissection, immunochemotherapy, and radiation therapy (RT). The type of surgery varied, based on anatomic location. 15 patients had attempted curative resections. Additionally, control of neck disease was achieved with the help of a modified radical neck dissection in the patient who presented with neck lymph node involvement (6 patients). Of the 15 patients who underwent upfront surgical resection, surgical margins were negative in 12 patients and positive in three patients. No patient underwent lymphoscintigraphy and sentinel node mapping.

All patients received postoperative RT to the involved sites of disease. The median radiation dose delivered 


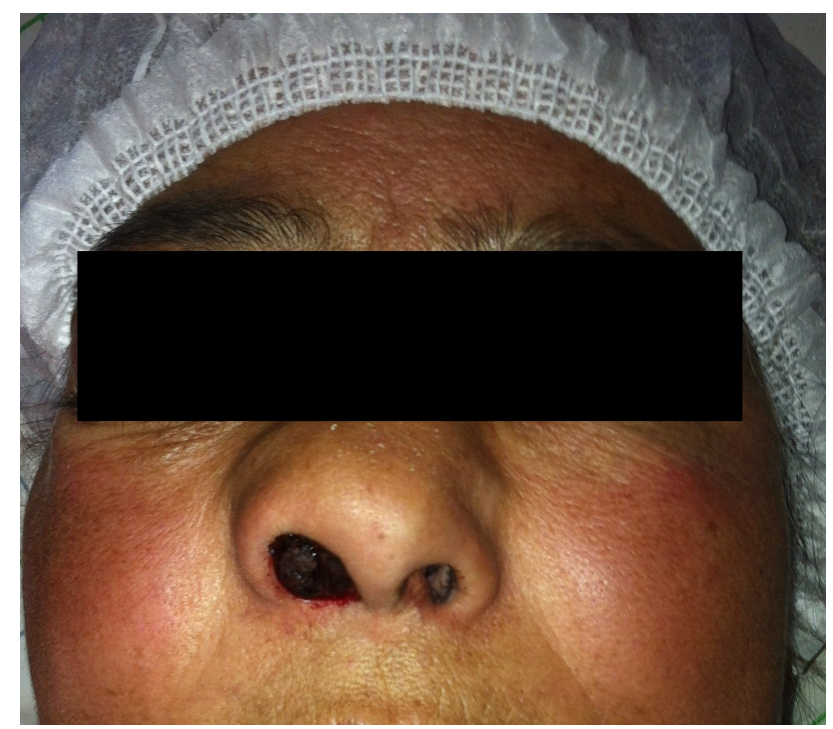

Figure 1. Photograph of A patient showing a black polypoidal mass in the left nasal cavity.

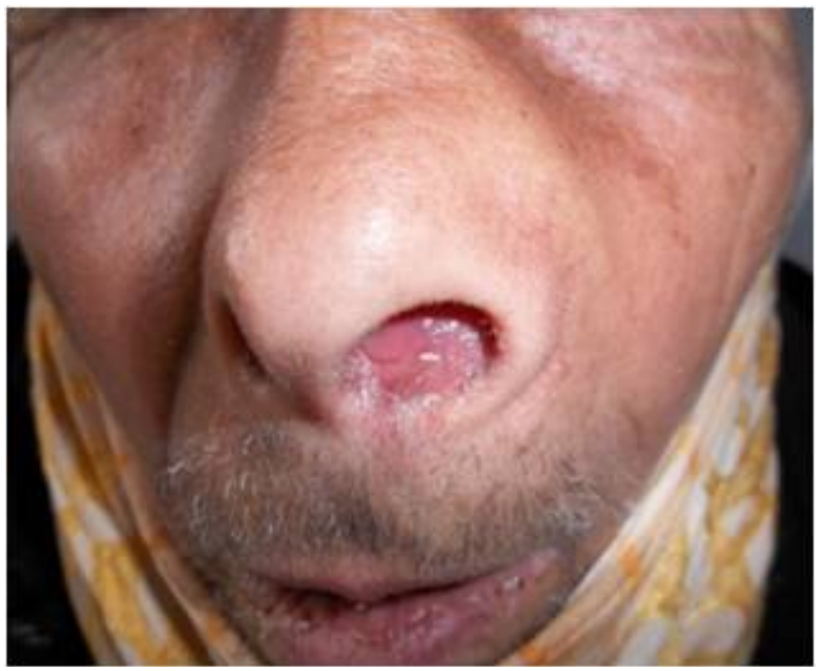

Figure 2. Not pigmented, melanoma involving the nasal cavity.

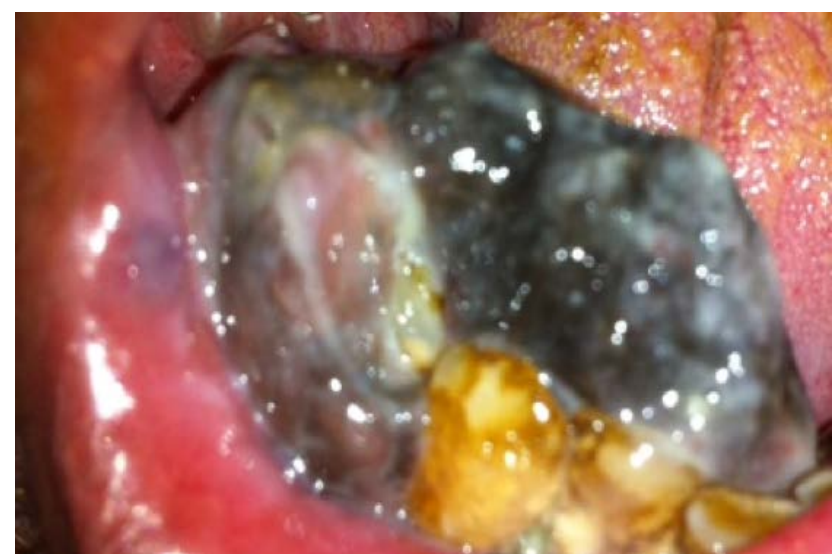

Figure 3. Macroscopic appearance of the oral tumor. 


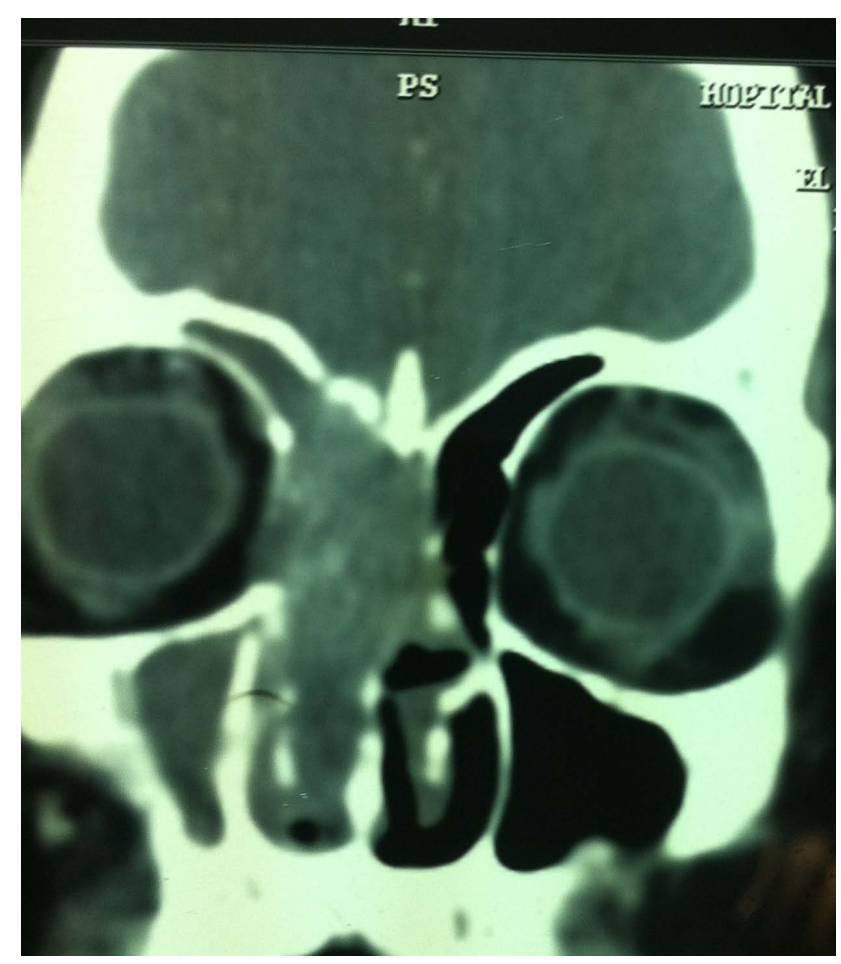

Figure 4. CT scan of paranasal sinuses, coronal view showing an extensive mass involving nasal cavity with signs of bony destruction.

was ranged from 30 to $70 \mathrm{~Gy}$, These patients typically received a total of 10 fractions over 2 to 4 weeks to the involved sites of disease. Immunochemotherapy was administered in an adjuvant fashion to surgery in all patients, the protocol included DTC (dimethyltriazeno-imidazole-carboxamide), ACNU (nimustine hydrochloride), and VCR (vincristine), which is also known as the DAV protocol. Using this aggressive approach; a combination of surgery, RT, and/or systemic therapy; we had just 3 patients recurred at follow-up. Of these patients, two patients recurred locally and one distantly. Two patients received palliative radiation therapy as the primary treatment and immunochemotherapy as the adjuvant treatment. Eventually, these patients developed liver and pulmonary metastases.

All patients were followed in regular intervals by clinical, endoscopic and radiological examination. A MRI control was made in the 6th and 12 th month follow-up. The local control rates vary from approximately 50\% to $70 \%$ at 5 years.

Although the majority of recurrences are observed within 15 to 29 months after treatment.

Overall survival (OS) was defined as the time from surgery/biopsy to death from any cause, with surviving patients censored at date of last follow-up. Surgery with adjuvant medical treatment seems to be effective for local control of the disease. Survival ranged between 5 to >61 months (patient alive at 61 months), In comparison with other studies, our patients, who received a combination of surgery radiotherapy and immunochemotherapy had the longest survival (Table 1 and Table 2).

\section{Discussion}

Primary mucosal melanomas represent only $1.7 \%$ - 3\% of all primary melanomas [1]-[3]. The most frequent head and neck site of occurrence of mucosal melanoma is the conjunctiva, followed by the upper respiratory tract and the oral cavity [6]. The majority of the upper respiratory tract arises from the nasal cavity (80\%) and the rest from the sinuses (20\%). Common sites in order include the nasal septum, lateral nasal wall, turbinates, and nasal vestibule [3] [4] [6]. The maxillary sinus was the most commonly involved site among the paranasal sinuses accounting for $6 \%$ of all mucosal melanoma followed by the ethmoid, frontal, and sphenoid sinus cavities [3] [4]. In this study, we found that the maxillary sinus was the most commun site of the sino nasal melanoma. 
Table 1. Clinical and treatment data of the patients with sinonasal melanoma.

\begin{tabular}{|c|c|c|c|c|c|c|c|c|}
\hline \multirow{2}{*}{$\begin{array}{l}\text { Age } \\
\text { gender }\end{array}$} & \multirow{2}{*}{ Symptome } & \multirow{2}{*}{ Primary site } & \multicolumn{2}{|c|}{ Classification } & \multirow{2}{*}{ Primary treatment } & \multirow{2}{*}{ Adjuvant treatment } & \multirow{2}{*}{ Lymph node } & \multirow{2}{*}{ Evolution } \\
\hline & & & Ballantyne & TNM & & & & \\
\hline 61 female & $\begin{array}{c}\text { Epistaxis } \\
\text { nasalobstruction }\end{array}$ & Maxillary sinus & I & T3 & $\begin{array}{c}\text { Surgery } \\
\text { (paralateronasal) }\end{array}$ & $\begin{array}{l}\text { Immunochemotherapy } \\
\text { radiation }\end{array}$ & & $\begin{array}{c}\text { Alive at } 11 \\
\text { months }\end{array}$ \\
\hline 65 female & $\begin{array}{c}\text { Epistaxis } \\
\text { facial pressure }\end{array}$ & Maxillary sinus & II & $\mathrm{T} 4$ & $\begin{array}{c}\text { Surgery } \\
\text { (paralateronasal) }\end{array}$ & $\begin{array}{l}\text { Immunochemotherapy } \\
\text { radiation }\end{array}$ & $\mathrm{N}+$ & $\begin{array}{c}\text { Death at } 10 \\
\text { months }\end{array}$ \\
\hline 67 female & nasalobstruction & Nasal cavity & I & $\mathrm{T} 1$ & $\begin{array}{l}\text { Surgery } \\
\text { endonasal }\end{array}$ & $\begin{array}{l}\text { Immunochemotherapy } \\
\text { radiation }\end{array}$ & & $\begin{array}{c}\text { Alive at } 61 \\
\text { months }\end{array}$ \\
\hline $\begin{array}{l}W<68 \\
\text { female }\end{array}$ & $\begin{array}{c}\text { Epistaxis } \\
\text { nasalobstruction }\end{array}$ & Septum & I & $\mathrm{T} 1$ & $\begin{array}{c}\text { Surgery } \\
\text { (paralateronasal) }\end{array}$ & $\begin{array}{l}\text { Immunochemotherapy } \\
\text { radiation }\end{array}$ & & $\begin{array}{c}\text { Alive at } 42 \\
\text { months }\end{array}$ \\
\hline 68 female & epistaxis & $\begin{array}{l}\text { Nasal cacity } \\
\text { (cornet inf) }\end{array}$ & I & $\mathrm{T} 1$ & $\begin{array}{l}\text { Surgery } \\
\text { endonasal }\end{array}$ & $\begin{array}{l}\text { Immunochemotherapy } \\
\text { radiation }\end{array}$ & & $\begin{array}{c}\text { Alive at } 18 \\
\text { months }\end{array}$ \\
\hline 72 female & $\begin{array}{l}\text { epistaxis facial } \\
\text { pressure }\end{array}$ & Maxillary sinus & III & $\mathrm{T} 4$ & $\begin{array}{c}\text { Surgery } \\
\text { (paralateronasal) }\end{array}$ & $\begin{array}{l}\text { Immunochemotherapy } \\
\text { radiation }\end{array}$ & $\mathrm{M}+$ & $\begin{array}{c}\text { Death at } 07 \\
\text { months }\end{array}$ \\
\hline $\begin{array}{c}75 \\
\text { female }\end{array}$ & $\begin{array}{c}\text { Epistaxis } \\
\text { nasalobstruction }\end{array}$ & Nasoethmoidal & I & $\mathrm{T} 3$ & $\begin{array}{c}\text { Surgery } \\
\text { (paralateronasal) }\end{array}$ & $\begin{array}{l}\text { Immunochemotherapy } \\
\text { radiation }\end{array}$ & & $\begin{array}{l}\text { Alive at } 16 \\
\text { months }\end{array}$ \\
\hline 61 male & $\begin{array}{l}\text { epistaxis facial } \\
\text { pressure }\end{array}$ & Maxillary sinus & II & $\mathrm{T} 4$ & $\begin{array}{c}\text { Surgery } \\
\text { (paralateronasal) }\end{array}$ & $\begin{array}{l}\text { Immunochemotherapy } \\
\text { radiation }\end{array}$ & $\mathrm{N}+$ & $\begin{array}{l}\text { Death at } \\
6 \text { months }\end{array}$ \\
\hline $\begin{array}{l}67 \\
\text { male }\end{array}$ & facial pressure & Maxillary sinus & I & $\mathrm{T} 3$ & $\begin{array}{c}\text { Surgery } \\
\text { (paralateronasal) }\end{array}$ & $\begin{array}{l}\text { Immunochemotherapy } \\
\text { radiation }\end{array}$ & & $\begin{array}{l}\text { Death at } \\
9 \text { months }\end{array}$ \\
\hline $\begin{array}{c}68 \\
\text { male }\end{array}$ & $\begin{array}{l}\text { epistaxis facial } \\
\text { pressure }\end{array}$ & Maxillary sinus & I & $\mathrm{T} 1$ & $\begin{array}{c}\text { Surgery } \\
\text { (paralateronasal) }\end{array}$ & $\begin{array}{l}\text { Immunochemotherapy } \\
\text { radiation }\end{array}$ & & $\begin{array}{c}\text { Alive at } 51 \\
\text { months }\end{array}$ \\
\hline $\begin{array}{c}71 \\
\text { male }\end{array}$ & $\begin{array}{c}\text { Epistaxis } \\
\text { nasalobstruction }\end{array}$ & Nasal cavity & I & $\mathrm{T} 1$ & $\begin{array}{l}\text { Surgery } \\
\text { endonasal }\end{array}$ & $\begin{array}{l}\text { Immunochemotherapy } \\
\text { radiation }\end{array}$ & & $\begin{array}{c}\text { Alive at } 31 \\
\text { months }\end{array}$ \\
\hline 73 male & $\begin{array}{c}\text { Epistaxis } \\
\text { nasalobstruction }\end{array}$ & Nasal septum & I & $\mathrm{T} 1$ & $\begin{array}{c}\text { Surgery } \\
\text { (paralateronasal) }\end{array}$ & $\begin{array}{l}\text { Immunochemotherapy } \\
\text { radiation }\end{array}$ & & $\begin{array}{c}\text { Alive at } 30 \\
\text { months }\end{array}$ \\
\hline
\end{tabular}

Table 2. Clinical and treatment data of the patient with oral melanoma.

\begin{tabular}{|c|c|c|c|c|c|c|c|c|}
\hline \multirow{2}{*}{$\begin{array}{l}\text { Age } \\
\text { gender }\end{array}$} & \multirow{2}{*}{ Symptome } & \multirow{2}{*}{ Primary site } & \multicolumn{2}{|c|}{ Classification } & \multirow{2}{*}{$\begin{array}{l}\text { Primary } \\
\text { treatment }\end{array}$} & \multirow{2}{*}{$\begin{array}{l}\text { Adjuvant } \\
\text { treatment }\end{array}$} & \multirow{2}{*}{ Lymph node } & \multirow{2}{*}{ Evolution } \\
\hline & & & Ballantyne & TNM & & & & \\
\hline $\begin{array}{c}68 \\
\text { male }\end{array}$ & $\begin{array}{l}\text { Gingivorragia } \\
\text { bleeding lump } \\
\text { cervical node }\end{array}$ & Hard palate & II & $\mathrm{T} 1$ & $\begin{array}{l}\text { Wide local } \\
\text { excision }\end{array}$ & $\begin{array}{l}\text { Immunochemotherapy } \\
\text { radiation }\end{array}$ & $\mathrm{N}+$ & $\begin{array}{c}\text { Alive at } 42 \\
\text { months }\end{array}$ \\
\hline $\begin{array}{c}71 \\
\text { male }\end{array}$ & $\begin{array}{l}\text { Facial pain } \\
\text { gingivorragia }\end{array}$ & Hard palate & II & $\mathrm{T} 4$ & - & $\begin{array}{l}\text { Immunochemotherapy } \\
\text { radiation }\end{array}$ & $\mathrm{N}+$ & $\begin{array}{c}\text { Death at } 09 \\
\text { months }\end{array}$ \\
\hline 73 male & $\begin{array}{c}\text { Gingivorragia } \\
\text { pigmented lesion }\end{array}$ & $\begin{array}{l}\text { Mandibular } \\
\text { gingiva }\end{array}$ & I & $\mathrm{T} 1$ & Alveolectomy & $\begin{array}{l}\text { Immunochemotherapy } \\
\text { radiation }\end{array}$ & $\mathrm{N}+$ & $\begin{array}{c}\text { Alive at } 22 \\
\text { months }\end{array}$ \\
\hline 68 female & Bleeding lump & Buccal mucosa & III & $\mathrm{T} 4$ & - & $\begin{array}{l}\text { Immunochemotherapy } \\
\text { radiation }\end{array}$ & $\begin{array}{l}\mathrm{N}+ \\
\mathrm{M}+\end{array}$ & $\begin{array}{c}\text { Death at } 05 \\
\text { months }\end{array}$ \\
\hline 72 female & Bleeding lump & Alveolar ridge & II & $\mathrm{T} 1$ & Alveolectomy & $\begin{array}{l}\text { Immunochemotherapy } \\
\text { radiation }\end{array}$ & $\mathrm{N}+$ & $\begin{array}{c}\text { Alive at } 28 \\
\text { months }\end{array}$ \\
\hline
\end{tabular}

Oral mucosa is the second most common site of head and neck mucosal melanoma, representing $0.2 \%$ to $8 \%$ of all melanomas and $0.5 \%$ of all oral malignancies [1] [6], with nearly $70 \%$ arising in the upper alveolus and hard palate [3]. We found similar results in accordance with the literature. Oropharyngeal and laryngeal mucosal melanomas are exceedingly rare and only mentioned in case reports [1] [4] [6].

Generally, oral cavity melanoma appears to occur at a younger age than sinonasal mucosal melanoma [4]. Such a difference was not found in our study.

Sinonasal mucosal melanoma has typical presentations of epistaxis, nasal obstruction, facial deformity and facial pain. Typically, sinonasal mucosal melanoma presents as an expansive mass encroaching on several sub- 
sites of the paranasal sinuses, orbit, or cranial fossa and more than likely not pigmented [3] [4]. Symptoms of oral melanomas vary and include a bleeding lump and, rarely, pain. The diagnosis is often unfortunately delayed until symptoms resulting from ulceration, growth, or bleeding are noted [1] [2] [6].

Oral lesions are often flat and pigmented. These patients are often asymptomatic at time of presentation, and by this time, significant vertical invasion of the tumor cells into the underlying tissues has already occurred [1] [2] [6].

Unlike their skin counterparts, mucosal melanomas cannot be classified into the cutaneus melanomas categories due to different clinical and histologic characteristics. Patients may be staged according to the American Joint Committee on Cancer staging system. Alternatively, tumors may be stratified as follows according to UICC (Union Internationale Contre le Cancer) staging: stage I, confined to the primary site; stage II, positive cervical lymph nodes; and stage III, distant metastases [5] [6].

Mucosal melanoma must always be considered for multimodality therapy: surgical excision, medical oncology, and radiation therapy [5] [6]. 25\% of patients with oral mucosal melanoma present with neck metastasis while only $6 \%$ of sinonasal melanoma patient present initially with neck involvement [3] [4]. In this paper, 5/5 patients with oral melanoma had cervical lymph nodes in time of presentation and just 2/12 patients with sinonasal had cervical lymph nodes (Figure 5).

Sentinel Lymph Node Biopsy in the Head and Neck. The widespread use of sentinel lymph node (SLN) biopsy in the management of head and neck melanoma has been limited by several concerns. One is that the lymphatic drainage in the head and neck region is complex, with multiple primary channels and the potential for multiple SLN sites.

Secondarily excision of these nodes can be technically challenging as small distances between sentinel nodes make detection and isolation difficult. Furthermore, approximately $25 \%$ - 30\% of the sentinel nodes is found within the parotid gland, and concern of facial nerve injury has led many surgeons to advocate superficial parotidectomy over SLN biopsy.

And lastly, the cooperation of experienced pathologists and nuclear medicine staff are essential to the success of the procedure. But it still remains an area for future evaluation [1] [4] [7] [8].

For oral mucosal melanoma, the topic of prophylactic neck dissections has been debated more due to the greater frequency of regional metastasis upon initial presentation. The rate of regional recurrence in oral mucosal melanomas is much greater, estimated around 70\% [2] [5] [6]. Prophylactic neck dissections in treatment of sinonasal mucosal melanoma are not advocated.

Metastatic disease should be evaluated for at onset including CT Chest and PET/CT.

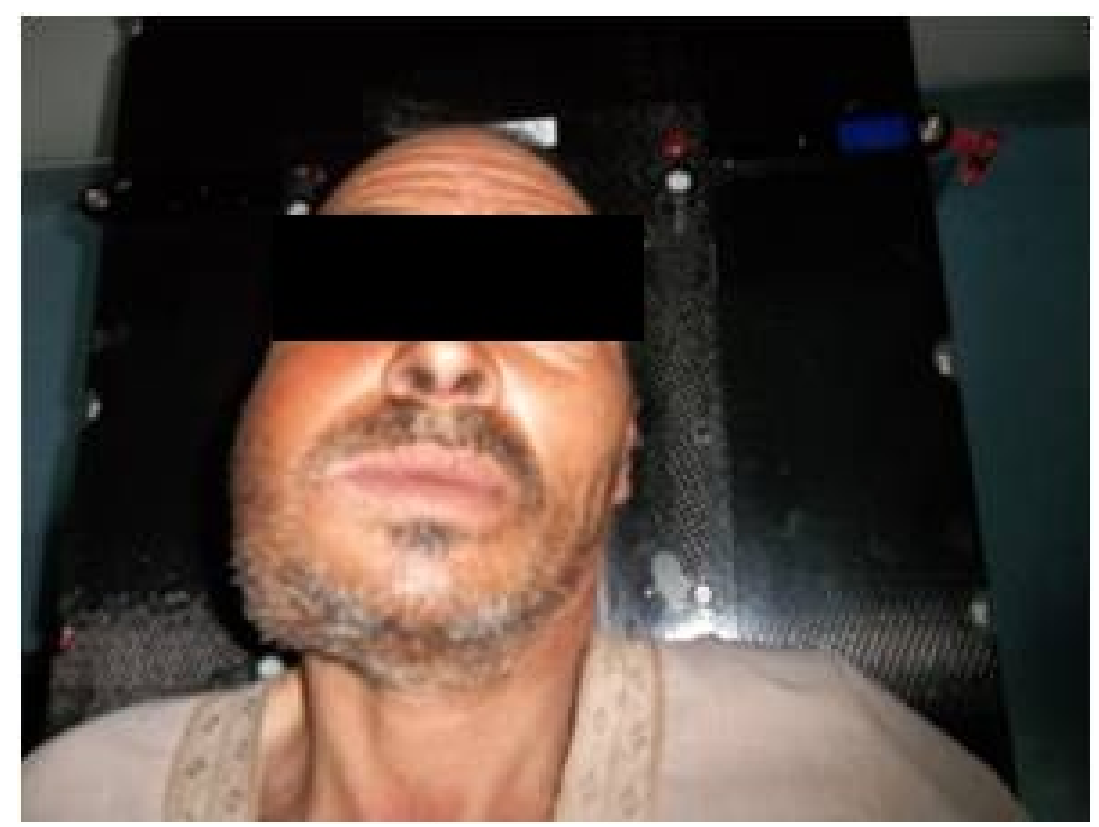

Figure 5. Patient with oral melanoma and nodal involvement. 
Unlike cutaneous melanoma, the common sites of distant metastasis are the lungs (33\%) and brain (14\%), with multiple sites being involved in 33\% of cases in the literature [3]-[5]. In this study we found that two patients had a distant metastasis, at initial presentation, in multiple sites; lung and liver: (1 patients), brain and liver (1 patient).

Despite its radioresistant nature of tumor, the role of radiation therapy following surgical intervention has typically been advocated. However, the topic of primary radiation therapy has been debated. Gaze et al. demonstrated complete clinical response in 8/13 patients with primary radiation therapy alone [9]. Remainder of studies advocate radiotherapy for inoperable tumors or recurrence.

Post-operative radiation therapy has shown to improve local control in several retrospective series. Benlyazid et al. demonstrated greater improved local control (62\% vs 26\%) in patients treated surgery and radiation therapy versus those with surgery alone [10]. Similarly, Owens et al. found similar benefit with $83 \%$ vs 55\% in comparing those patient receiving surgery with post-operative radiation therapy and those receiving surgery alone [11].

The authors of a series from the University of Florida agree that surgery with postoperative RT should be used in nearly all cases of head and neck mucosal melanomas. However, they also suggest that elective nodal irradiation should be used to address subclinical regional disease [12]. In this study we have use an aggressive approach: a combination of surgery, RT, and immunochemotherapy, and we found that Surgery with adjuvant medical treatment seems to be effective for local control of the disease. Survival ranged between 05 to $>61$ months (alive at 61 months), In comparison with other studies, our patients had the longest survival. Although this is a very small sample of patients; this result is in accordance with the treatment recommended by many authors. More studies are needed to determine treatment modalities, prophylactic neck dissection, adjuvant treatment, the prognostic value of tumor thickness and invasion of mucosal melanoma. This would also help to establish a clinically useful classification of mucosal melanomas and thus to improve therapy.

The final area of treatment lies with immunochemotherapy. KIT gene has been identified in nearly 15\% - 30\% of mucosal melanoma cases. Some preliminary studies have even suggested that treatment with a KIT inhibitor may lead one further year of survival.

The domain of medical oncology and genetic research may provide further clues, especially in light of preliminary benefits noted of KIT inhibitors [13]-[15].

\section{Conclusion}

The occurrence of primary mucosal melanoma is very rare. It is most frequently present in the nose and/or sinuses, followed by the oral cavity and nasopharynx. Head and neck melanoma is a complex disease especially in its treatment considerations. The prognosis remains poor despite adequate locoregional control of the disease. The generally advanced stage of the tumor at initial diagnosis leads to a poorer survival because of their development in hidden and clinically silent areas. As in any other cancer, the best opportunity for cure lies in early and aggressive treatment. Further research in the use of adjuvant therapy (chemotherapy, immunotherapy, biological therapy) will be necessary to improve the outcome of patients with mucosal melanoma.

\section{Conflict of Interest}

None.

\section{References}

[1] Shashanka, R. and Smitha, B.R. (2012) Head and Neck Melanoma. International Scholarly Research Network ISRN Surgery, 2012, Article ID: 948302.

[2] Greenberg, M.S. and Glick, K.M. (2008) Pigmented Lesions of the Oral Mucosa. In: Burket's Oral Medicine, 11th Edition, BC Decker, Hamilton, 586.

[3] Narasimhan, K., et al. (2009) Sinonasal Mucosal Melanoma: A 13-Year Experience at a Single Institution. Skull Base, 19, 255-262. http://dx.doi.org/10.1055/s-0028-1115321

[4] Rapidis, A., Apostolidis, C., Vilos, G. and Valsamis, S. (2003) Primary Malignant Melanoma of the Oral Mucosa. Journal of Oral and Maxillofacial Surgery, 61, 1132-1139. http://dx.doi.org/10.1016/S0278-2391(03)00670-0

[5] Gavriel, H., McArthur, G., Sizeland, A. and Henderson, M. (2011) Review: Mucosal Melanoma of the Head and Neck. Melanoma Research, 21, 257-266. http://dx.doi.org/10.1097/CMR.0b013e3283470ffd 
[6] Chang, A., Karnell, L. and Menck, H. (1998) The National Cancer Data Base Report on Cutaneous and Noncutaneous Melanoma: A Summary of 84,836 Cases from the Past Decade. The American College of Surgeons Commission on Cancer and the American Cancer Society. Cancer, 83, 1664-1678. http://dx.doi.org/10.1002/(SICI)1097-0142(19981015)83:8<1664::AID-CNCR23>3.0.CO;2-G

[7] Jethanamest, D., Vila, P.M., Sikora, S.G. and Morris, L.G.T. (2011) Predictors of Survival in Mucosal Melanoma of the Head and Neck. Annals of Surgical Oncology, 18, 2748-2756. http://dx.doi.org/10.1245/s10434-011-1685-4

[8] Leong, S.P., Accortt, N.A., Essner, R., Ross, M., Gershenwald, J.E., Pockaj, B., et al. (2006) Impact of Sentinel Node Status and Other Risk Factors on the Clinical Outcome of Head and Neck Melanoma Patients. Archives of Otolaryngology—Head Neck Surgery, 132, 370-373. http://dx.doi.org/10.1001/archotol.132.4.370

[9] Gaze, M.N., Kerr, G.R. and Smyth, J.F. (1990) Mucosal Melanomas of the Head and Neck: The Scottish Experience. The Scottish Melanoma Group. Clinical Oncology (Royal College of Radiologists), 2, 277-283. http://dx.doi.org/10.1016/S0936-6555(05)80955-0

[10] Benlyazid, A., Thariat, J., Temam, S., Malard, O., Florescu, C., Choussy, O., et al. (2010) Postoperative Radiotherapy in Head and Neck Mucosal Melanoma: A GETTEC Study. Archives of Otolaryngology—Head Neck Surgery, 136, 1219-1225. http://dx.doi.org/10.1001/archoto.2010.217

[11] Owens, J.M., Roberts, D.B. and Myers, J.N. (2003) The Role of Postoperative Adjuvant Radiation Therapy in the Treatment of Mucosal Melanomas of the Head and Neck Region. Archives of Otolaryngology—Head Neck Surgery, 129, 864-868. http://dx.doi.org/10.1001/archotol.129.8.864

[12] Wagner, M., Morris, C.G., Werning, J.W. and Mendenhall, W.M. (2008) Mucosal Melanoma of the Head and Neck. American Journal of Clinical Oncology, 31, 43-48. http://dx.doi.org/10.1097/COC.0b013e318134ee88

[13] Hodi, F.S., Friedlander, P., Corless, C.L., Heinrich, M.C., Mac Rae, S., Kruse, A., et al. (2008) Major Response to Imatinib Mesylate in KIT-Mutated Melanoma. Journal of Clinical Oncology, 26, 2046-2051. http://dx.doi.org/10.1200/JCO.2007.14.0707

[14] Quintás-Cardama, A., Lazar, A.J., Woodman, S.E., Kim, K., Ross, M. and Hwu, P. (2008) Complete Response of Stage IV Anal Mucosal Melanoma Expressing KIT Val560Asp to the Multikinase Inhibitor Sorafenib. Nature Clinical Practice Oncology, 5, 737-740. http://dx.doi.org/10.1038/ncponc1251

[15] Handolias, D., Salemi, R., Murray, W., Tan, A., Liu, W., Viros, A., et al. (2010) Mutations in KIT Occur at Low Frequency in Melanomas Arising from Anatomical Sites Associated with Chronic and Intermittent Sun Exposure. Pigment Cell Melanoma Research, 23, 210-215. http://dx.doi.org/10.1111/j.1755-148X.2010.00671.x 